Claudine Chamoreau (Paris)

\title{
Spanish diminutive markers -ito/-ita in Mesoame- rican languages A challenge for acceptance of gender distinction
}

\begin{abstract}
This paper explores patterns in the borrowing of the Spanish diminutive markers -ito/-ita in some languages of Mesoamerica. These borrowings are particularly interesting because they encode two different categories: the diminutive category, and the grammatical gender category which distinguishes between a masculine form -ito and a feminine form, -ita. In Mesoamerican languages that have adopted the Spanish diminutive marker, the first category is already attested while the second is absent from all languages except Yucatec Maya. The primary aim in this paper is to establish the reasons why these languages have borrowed these markers even though they possess a device for expressing the diminutive category. The relevant factor seems to be structural, that is, the adoption of a morphological mechanism. The second purpose of this paper is to explain how these languages borrowed a marker encoding gender distinction. Typological features of the replica languages are relevant for the acceptance of grammatical gender.
\end{abstract}

\section{Introduction}

This paper explores the patterns by which some languages of Mesoamerica have borrowed Spanish diminutive markers. In Spanish, the diminutive category is encoded by various forms: in (1) -ito/-ita, in (2) -cito/-cita, in (3) -illo/-illa (alongside other, less used forms: -cillo/-cilla, -ico/-ica, -etel-eta, etc.). Nevertheless, only the first two, in (1), have been reported as borrowings.
(1a) luegito ${ }^{1}$
'quite soon'
[luego 'soon'] $]^{2}$
(1b) una casita
'a little house'
[casa 'house']
(2a) un cochecito
'a cute little car'
[coche 'car']
(2b) una crucecita
'a little cross'
[cruz 'cross']
(3a) un bolsillo
'a pocket'
[bolso 'bag']
(3b) una parilla
'a grill
[parra 'climbing vine']

1 The examples in Spanish are transcribed orthographically.

2 In brackets are the words without the diminutive marker. 
The borrowing of these forms is particularly interesting because they encode two different categories: the diminutive category, and the grammatical gender category which distinguishes between the masculine form -ito and the feminine form, -ita. In Mesoamerican languages that have adopted Spanish diminutive markers, the first category is already attested while the second is absent from all languages except in Yucatec Maya (see 4.4).

The primary aim of this paper is to establish the reasons why these languages have borrowed these markers despite the fact that they already have a device for expressing the diminutive category. The relevant factor appears to be a structural motivation, that is, the adoption of a morphological mechanism. Additional factors are involved and interact: intensity of these languages' exposure to Spanish, frequency of use of the diminutive category in Spanish as well as in the replica languages, the semantic, formal and functional transparency of the markers. This paper presents a classification of the major patterns used by Mesoamerican languages for introducing the Spanish markers. An obvious question that arises is how languages lacking the gender distinction borrow an element that encodes this distinction. The answer to this question is highly tentative. I do think nonetheless that typological features of the replica languages are relevant for the acceptance of grammatical gender. This answer is based on behavioral differences between Yucatec Maya and the other languages.

This paper is organized as follows: Section 2 introduces previous research on morphological borrowing and on gender borrowing in languages lacking gender marking. Section 3 presents the use of the diminutive category in Spanish, the source language. Section 4 illustrates the diversity of native devices for the expression of diminutive and gender categories. Section 5 gives a detailed analysis of the use of the diminutive forms in the replica languages. The discussion in section 6 assigns the phenomenon under scrutiny a place in the catalogue of contact-induced morphological changes.

\section{Previous research}

Morphological elements are generally described as being more difficult to borrow than lexical ones, and to only arise under specific social circumstances, that is, intense contact situations (stage 3 or 4 in Thomason's 4 borrowing stages scale, Thomason 2001: 69-71).

If we focus on bound morphemes, some elements seem to be easier to borrow than others. In his typological study, Matras (2007: 44) asserts that "Borrowing of bound markers favors in particular plural markers, diminutive and agentive derivational markers, and classifiers (but not gender markers) [...]".

This statement is corroborated by studies on romancization processes (T. Stolz 2008: 21-22); but cf. T. Stolz (this volume). On the one hand, diminutive and agentive 
derivational marker borrowing is well-known: for example, the Spanish agentive suffix -dor is attested in Quechua and Chamorro, and the agentive marker -ero is productive in Chamorro and in Tagalog. Similarly, studies on contact linguistics from Spanish into native Mesoamerican languages show that a wide variety of elements can be borrowed: in various varieties of Nahuatl, the plural suffix (-s/-es), the agentive marker (-tero/-ero) and the diminutive markers (-to/-ita) (Suárez 1977, Hill \& Hill 1986). In Yucatec Maya, the agentive and diminutive markers are borrowed (C. Stolz 1998 cited by T. Stolz 2008: 22). In Balsas Nahuatl, the plural suffix and the agentive marker -ero are attested (Flores Farfán 1999). In Purepecha, only diminutive markers have been borrowed (Swadesh 1967, Chamoreau 2007).

On the other hand, there is a vast amount of literature on noun borrowings into languages with gender systems, although few studies relate particular cases of noun borrowing to the overall system (C. Stolz 2008, 2009). Corbett (1991: 70-82) examines different factors in the assignment of gender in the replica languages, in particular the mechanism of gender assignment through rules normal for native nouns, i.e., like the other nouns of the replica language. Nevertheless, these studies only focus on lexical borrowings, but not on specific morphological markers carrying gender distinction.

Gender marking is generally not borrowed or is only partially borrowed into languages lacking gender marking. For example, Tagalog has adopted the subsystem of Spanish gender marking and agreement -but those systems are fairly marginal in that they involve a limited set of items. Schachter \& Otanes (1972: 197) specify that

there is a small group of unaffixed adjectives [the commonest adjectives in Tagalog $]^{3}$ that are GENDER-MARKED. These adjectives, all of which are borrowed from Spanish, occur in two different forms: one ending in $-o / \mathrm{oh} /$, the other ending in $-a / \mathrm{ah} /$. The forms ending in $-a$ are used when adjectives refer to female human beings or female animals; the forms ending in $-o$ are used in all other cases: i.e., when the adjectives refer to male human beings or male animals, to groups including individuals of both sexes, to inanimate objects, to abstractions, etc.

Rapanui (Fischer 2007: 390-391) also has no gender marking, nor has it systematically borrowed gender marking from Spanish (T. Stolz 2002 and this volume). Nevertheless, isolated items are beginning to introduce it, such as gender-marked diminutive suffixes. In Mesoamerica, a few examples of gender marking introduction have been found in Otomi (Otopamean language) which does not usually mark gender, but now does in some native words as a result of contact with Spanish (Hekking \& Bakker 2007: 444).

3 My comment in brackets. 


\section{Diminutive markers in Mexican Spanish, the source language}

Spanish uses a morphological device to form diminutives. This category is encoded by various markers -ito/-ita, -cito/-cita, -illo/-illa (see above, examples (1), (2), and (3)). Nevertheless, only the first two have been reported as borrowings. This selective behavior may be explained by the fact that the -ito/-ita markers are the most frequent forms for the diminutive category in Spanish, representing 92\% of occurrences (Reynoso 2005).

These two markers encode the two elements of the Spanish gender system: masculine and feminine. Grammatical Spanish gender is complex, the relation between gender and its phonological representation is not always transparent, - $o$ typically marks the masculine and $-a$ the feminine, but this is not always the case. Thus gender must often be determined by looking at other members of the nominal phrase, that is the determiner and adjective forms (Aronoff 1994: 67-72, Corbett 1991: 214).

The diminutive category is very productive in the variety of Spanish spoken in Mexico and it is used for a large range of pragmatic purposes (Reynoso 2001). Diminutive markers can be added to nouns (ex. (4), (5), (6), (11), (12), (13) and (14)), as well as to adverbs (9) and to adjectives (10). There are two types of meanings: in the classification below, in A one finds descriptive meanings and in B, subjective and metaphorical meanings. The central meaning of the diminutive category is descriptive, it refers to 'small' and 'child'. Jurafsky (1996: 543) indicates that these meanings are "historically prior and metaphorically and inferentially motivate the other senses, and second, that if the diminutive in a particular language has a sense, it will have each prior sense on some path to the root. Thus any language with a diminutive with a 'member' sense will have a 'child' sense."

\section{A. Descriptive meaning (quantification - characterization of the referent)}

To indicate that something or someone is either small in size or young ('child sense').

(4) mi perrito 'my little dog' [perro 'dog']

(5) mi niñito 'my young boy' [niño 'boy']

B. Subjective meaning (qualification - attitude of the speaker)

Positive intentions

B1. To indicate that something is endearing, this is a hypocoristic use (with affection or respect)

(6) mi abuelita 'my dear grandmother'

[abuela 'grandmother']

(7) mi perrito 'my doggy'

[perro 'dog'], (to a full-grown beloved pet) 
(8) el muertito 'dead person (with respect)' [muerto 'dead person'] (to a 6-foot tall old man)

B2. To provide a nuance of meaning (avoid unpleasant reality, such as intensification in (9) and attenuation in (10))

(9) Ahorita voy

'Right now I go.' [ahora 'now']

(10) Este hombre es gordito. 'This man is chubby.' [gordo 'fat']

B3. To add a friendly or polite tone (to minimize imposition on the hearer)

(11) Quisiera un refresquito. 'I would just like a soda.' [refresco 'soda']

B4. To indicate that something is unimportant (less severe, to soften or weaken the illocutionary force of the utterance as a whole).

(12) Le dije una mentirita. 'I have told him a fib.' [mentira 'lie']

B5. To talk to very young children

(13) Pon tu camisita. 'Put your T-shirt on.' [camisa 'shirt']

Negative intentions

B6. To form diminishment pejoratives (to depreciate) - generally with specific intonation

(14) ¿Oiste al diputadito? 'Did you hear the little deputy?' [diputado 'deputy']

(15) iEse fue un conciertito! 'That was a bad concert! [concierto 'concert']

\section{Native devices for expressing diminutives and gender categories}

\subsection{Sample}

The sample of Mesoamerican languages is constituted by the languages for which data have been published or for which linguists have accepted to share their data with me. The languages belong to four families (see map in the appendix). First, the Uto-Aztecan family, for which I have examined four varieties of Nahuatl: ${ }^{4}$ Mexicanero de la Sierra Madre Occidental, Acaxochitlán Nahuatl, Central Mexicano, Balsas Nahuatl. Second, I have analyzed Purepecha (formerly known as Tarascan), which is classified as a language isolate and not always as a Mesoamerican language (Smith Stark 1994, C.

4 Nahuatl has several varieties (perhaps even several languages, as not all the varieties of Nahuatl are mutually intelligible). 
Stolz \& T. Stolz 2001). Third is Tepehua, a Totonac-Tepehua language, and finally Yucatec Maya, which belongs to the Yucatecan branch of the Mayan family.

\subsection{Sociolinguistic setting}

The intensity of exposure of these languages to Spanish varies; it is nonetheless possible to characterize it as high in terms of duration -almost five centuries-and of cultural and socioeconomic dominance of the monolingual Spanish speaking group.

The degree of interference of these languages with Spanish is at approximately Stage 3 ('more intense contact') or 4 ('intense contact') on Thomason's borrowing scale. At these stages, "derivational affixes may be borrowed. [...] In morphology, borrowed inflectional affixes and categories may be added to native words, especially if they fit well typologically with previously existing patterns." (Thomason 2001: 69-70).

\subsection{Replica language mechanisms}

In Mesoamerican languages, the diminutive category may be expressed through three cross-linguistically well-known forms (Jurafsky 1996: 534): a shift in consonants and vowels, analytic construction (or lexical mechanism) and morphological mechanism.

\subsubsection{Phonological mechanism of consonant symbolism}

Tepehua uses a phonological process of consonant and vowel symbolism in order to express diminutive and affectionate speech: "In the Tepehua diminutive, the palatoalveolar fricatives and affricates are fronted to alveolars; the uvular stops are fronted to velars; and the mid-vowels /e/ and /o/ are raised to /i/ and /u/, respectively" (Kung 2007: 148). For example:

Tepehua (Kung 2007: 148)

(17) lhoqoqo 'something hollow' sukuku 'small hollow thing'

\subsubsection{Lexical mechanism with a morpheme meaning 'small, little'}

For diminutives, Tepehua also uses the lexical morpheme lakat'ikst'i meaning 'small, little':

5 When an example is quoted, I reproduce the author's transcription. 
Tepehua (Kung 2007: 150)

(18) lakat'ikst'i 'ts'o? 'birdy, little bird'

This is a very frequent strategy, also found in Purepecha in (19) and in Yucatec Maya in (20). This process is used for descriptive meaning, as in (19a) and (20a) or for subjective meaning, e.g. affection, in (19b) and (20b).

\section{Purepecha ${ }^{6}$}

(19a) tsttstki sapitfu 'little flower'

(19b) tststki sapitfu 'lovely flower, my darling' (for a girl)

Yucatec Maya (Briceño Chel 2009 personal communication)

(20a) táan u ch'i-ch'iankil le chan ch'íich'-o'

DUR A3SG RED-peck DEM little bird-DEM

'The little bird pecks and pecks.'

(20b) ko'oten waýe' chan xi'ipal

come.IMP.2SG here little boy

'Come here, little boy.'

\subsubsection{Morphological markers}

Nahuatl has several markers to express diminutives. Launey (1981: 107) indicates that the suffix -tsin (-tsi, -tzin) was originally a diminutive marker, but in Classical Nahuatl it essentially functions as a marker for subjective meaning, such as respect or affection, as in (21).

Classical Nahuatl (Launey 1981: 107)

(21) in chichi-tzin 'This (loyal) dog.'

As an honorific marker, it is found in the majority of the current varieties of Nahuatl. For example, in Central Mexicano in (22), or in Mexicanero de la Sierra Madre Occidental, in (23):

Central Mexicano (Hill \& Hill 1986: 146)

(22a) tlen mo-tōca 'What is your name?' (an adult asking a child)

(22b) tlen mo-tōca-tzīin 'What is your name? (a child asking an adult)

Mexicanero de la Sierra Madre Occidental (Canger 2001: 37)

(23a) no-ta-tsi 'my beloved father'

(23b) mo-ta-tsi 'your beloved father'

For Balsas Nahuatl, Flores Farfán (1999: 103) indicates that this marker is rare. When it appears as in (24), it generally corresponds to a descriptive meaning with respect to size:

6 The Purepecha data come from my own corpus. 
Balsas Nahuatl (Flores Farfán 1999: 105)

(24) Ø-tlaxcal-tsi-tsiin-teh

3-tortilla-PL-DIM-PL

'There are small tortillas'

In Classical Nahuatl, two other suffixes are used as diminutives; -tōn is generally used with descriptive meaning, as in (25) and -pil in (26), which is used to denote tenderness:

Classical Nahuatl (Launey 1981: 108)

(26) tōtō-pil 'tiny bird'

Launey mentions (1981: 110) that in Classical Nahuatl the morpheme tepi- 'small' always takes the suffix -tōn (tepi-tōn means 'small in size') or the suffix -tzin (tepi-tzin means 'small in quantity' for uncountable elements).

The suffix -ton is attested in current Nahuatl as spoken in Central Mexico, as in (27), in Acaxochitlán Nahuatl. It is pronounced -to:

Acaxochitlán Nahuatl - Hidalgo (Lastra de Suárez 1980: 72)

$\begin{array}{llll}\text { in } & \text { telpoka-to } & k i-n e k i & k o c ̌ i-s \\ \text { ART } & \text { boy-DIM } & \text { 3OBJ.SG-want } & \text { sleep-FUT }\end{array}$

'The little boy goes to sleep.'

\subsection{The category of gender in replica languages}

In Nahuatl (Launey 1981) and in Tepehua (Kung 2007: 366), there is no case, gender, or class marking on nouns. In Purepecha (Chamoreau 2009: 57-60), there is no grammatical gender. Numeral classifiers existed, but are less used today.

Yucatec Maya has numeral classifiers and markers that are generally called 'gender prefixes' among Mayanists. Some nouns are preceded by $a j-/ j$ - and $i x-/ x$-, masculine and feminine respectively (Lois 1998: 224-225). For example:

Yucatec Maya (Quintal 1999: 7)
(29a) waaj 'bread'
j-meenwaaj 'baker' (masculine)
(29b) janal 'food'
$\sim \quad x$-meenjanal 'cook' (feminine)

Yucatec Maya (Lois \& Vapnarsky 2006: 97-98)

(30a) u-ts'àak $j$ mèen

A3-cure MASC curer/medicine man/shaman

'the shaman's medicine/cure'

$\begin{array}{lllll}\text { (30b) tu'ux } & \text { yàan } & u & \boldsymbol{x} \text {-bay } & \text { Jwàan } \\ \text { where } & \text { EXIST } & \text { A3SG } & \text { FEM-bag } & \text { John }\end{array}$

'Where is John's bag?' 
These two markers may function as agentive markers as in (29) and (30a). Different uses for these markers exist: according to Victoria Bricker (quoted in Lois 1998: 227),

$h$ and $x$ are widely used with personal names in Yucatec: for example, $h$-piil 'Felipe' and x-piil 'Felipa' (while in Itzaj, another Yucatecan language, this use is pervasive). They can also appear with surnames to refer to members of a lineage or surname group, such as $h$-yah and $x$-yah, h-báalam, and $x$-báalam.

Other uses are with nouns for natural phenomena (moon, stars, wind, etc.) and with place-names to refer to someone from a specific town or region, e.g., $x$-ho'il 'woman from Merida' (Lois 1998: 241). There is a large category of nouns marked by $x$, namely instrumental nouns, for example $x$-chakab 'pot' from chak 'boil, parboil'; $x$-ts'ikib 'razor blade' from $t s^{\prime} i k$ 'shave' (also see example (30b)). The markers $h / x$ are also used with plant and animal names in Yucatec Maya (see Lois 1998, for a detailed study).

The $a j-/ j-$ and $i x-/ x$ - markers generally show determiner status (Lois 1998: 233) and no agreement exists in gender.

\section{Spanish diminutive markers in the replica languages}

The classification of the constructions with Spanish diminutive markers shows three different patterns. In certain languages, Spanish diminutive markers represent a lexical borrowing because they are associated with a lexical element (first names or Spanish borrowings). In other languages, only one marker is borrowed, this is always the -ito form. Finally, in Yucatec Maya, both markers are borrowed.

The following classification also shows that in the majority of the languages, no gender distinction is observed. When a Spanish diminutive marker is borrowed and used with a native element, the form is always -ito. I consider -ito as the unique form for the diminutive category in these languages, since -ita is only used with borrowed words. In Yucatec Maya, the two Spanish diminutive markers are accepted, and along with them the gender distinction but no agreement.

On the semantic level, the diminutive category is generally used to express affection, to refer to someone small in size or young in age, or to provide a given shade of meaning (such as intensification or attenuation).

\subsection{Lexical borrowings}

\subsubsection{Only with Spanish first names}

In this type, the use of the Spanish diminutive forms is limited to borrowed Spanish first names. This is the case in Tepehua. Both Spanish markers (-ito/-ita) are used and 
respect the gender of the first name. In example (31), the feminine marker -ita marks a feminine first name.

Tepehua (Kung 2007: 111)

(31) hu: susana-ita lak-p’uf-li hu: lak-Pa:la:fu:f

ART Susan-DIM 3PL.OBJ-pick-PFV ART PL-orange

'Susanita picked the oranges.'

The gender distinction is respected since it is biologically based and it is part of the first name's form. This context of use is attested in all the languages which borrow the Spanish diminutive forms, as well as in the languages where the Spanish diminutive markers are not described as borrowings. For this reason, the borrowing of first names along with the diminutive marker does not mean that the diminutive markers are borrowed. This is a lexical borrowing: what is borrowed is not the diminutive marker but the first name, in a form very commonly used in Spanish as spoken in Mexico.

\subsubsection{Restrictions to Spanish borrowings}

González Casanova (1933: 715) claims that Spanish diminutive markers are attested in some substantives borrowed from Spanish into Nahuatl, which is spoken in Central Mexico (called Aztecan language by the author), as in (32):

Central Nahuatl (González Casanova 1933: 715)

(32a) huerfan-ito 'orphan, poor' [huerfano]

(32b) colmen-ita 'hive, bee" [colmena]

Hill \& Hill (1986: 194-195) corroborate that "the diminutive is restricted to Spanish words" and specify that "usually, the Mexicano diminutive -tzin and the Spanish diminutive -ito/-ita are split between words from the two languages", as in (33). Certain borrowings appear in Nahuatl more frequently with the diminutive form: comadrita is more frequent than comadre: ${ }^{8}$

Central Mexicano (Hill \& Hill 1986: 195)

Mexicano adaptation Spanish words

(33a) comāleh-tzīn 'co-mother'/ comadr-ita 'co-mother' [comadre]

(33b) compäleh-tzīn 'co-father'/ compadr-ito 'co-father' [compadre]

Hill \& Hill (1986: 195) specify that Spanish diminutive markers have been recorded in "only one case in which it may occur on a Mexicano root":

7 In Spanish, colmena only means 'hive'. González Casanova explains that the change in meaning is due to its borrowing.

8 In Central Mexicano, Hill \& Hill (1986: 196) note the presence of the Mexicano honorific -tzin with Spanish words: madrináh-tzīn 'dear godmother'. 
Central Mexicano (Hill \& Hill 1986: 195)

(34a) nān-ita 'mother dear' [nān-tli]

(34b) nan-ita 'grandmother' (in local Spanish nanita exists as a nursery word) [nan-tli]

The two forms are used and the gender distinction is respected either because the elements are borrowed from Spanish (as in 32) or because they are biologically based (as in 33 and 34). In examples (32) and (33), it seems that the Nahuatl speakers have taken the form made up of the Spanish noun and the diminutive marker. They do not analyze the diminutive marker as a specific suffix; this is a lexical borrowing. On the contrary, in (34), the use of the diminutive -ita with a native Nahuatl noun is a clear borrowing of the marker.

\subsection{Borrowing of -ito}

\subsection{1. -ita with first names and -ito in all contexts}

In this type, the two forms are attested with first names, and respect the gender distinction. In example (35), in Purepecha, -ita is used for a woman elvirita and the masculine form, pronounced -itu, is used for a man, pukitu.

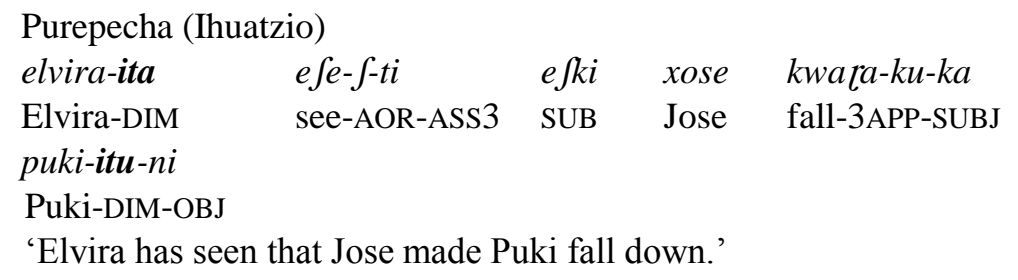

The feminine form only appears in this context. On the contrary, the masculine form is attested with Spanish borrowings such as animali in (36) and with native words such as watsi in (37). The -itu marker is well integrated in the complex Purepecha morphological system. It appears in the position of a derivative suffix, after nouns and before flexional suffixes: in example (36), before the plural suffix -et $\int a$, the adverbial clitic $=t \int k a$ and the personal clitic $=k s f$; in example (37), before the plural suffix $-e t \int a$ and the objective case marker $-n i$.

Purepecha (Santa Fe de la Laguna)

(36) yámintu animali-itu-et $\int a=t \int k a=k s t \quad$ senya $=s t \quad m a$ all animal-DIM-PL=well $=3 \mathrm{PL} \quad$ mark=FOC a ká-nka re-słn-ti possess-FACE-HAB-ASS3

'Well, there is a mark that all the little animals possess in the face.' 
epecha (Cocuchucho)

(37) witsintikwa $=k s t \quad$ ewa-kwa $\mathrm{e} e-a-s-t i$

yesterday $=3$ PL take-REF-3PL.OBJ-AOR-ASS3

watsi-itu-etfa-ni inte wali-ni

boy-DIM-PL-OBJ DEM woman-OBJ

'Yesterday, they had taken the little boys to this woman.'

It is relevant to notice that -itu is used in contexts with female reference, as in (38) where there is no agreement between Rosa-ita (with clear female reference) and xantiakhu-itu. The gender distinction is neutralized on items other than first names, and -itu is treated as the sole diminutive form. In (38), the marker is used with an adverb.

(38) Rosa-ita phakha-ra- $\int-t i$

xantiakhu-itu

Rosa-DIM stay-MID-AOR-ASS3 alone-DIM

'Rosita stayed completely alone.'

Example (38) shows that in Purepecha there is no agreement between the substantive (with -ita) and the adverb (with -itu). An obvious question that arises is whether the presence of -itu is obligatory in all contexts or if it is constrained by a specific context? My answer will be tentative because very few examples have been found. All the examples show that the -itu form is the sole form used when the morpheme is not a first name, whatever the phonetic context preceding -itu, for example /u/ in (38) and /i/ in the adjective sapilati (39).

Purepecha (Santa Fe de la Laguna)

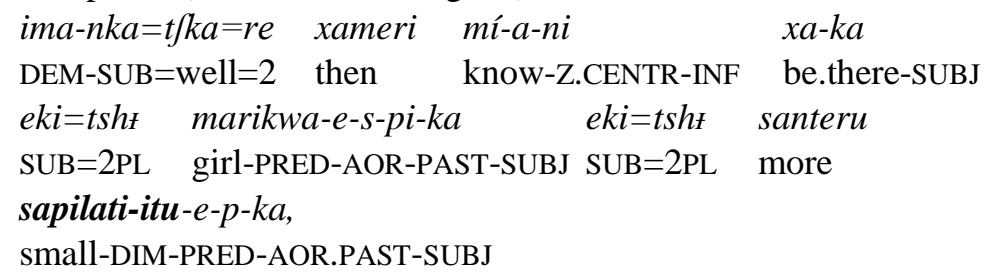

'Well, you, then, you remember when you were a girl, when you were very young.'

The gender distinction is only respected with first names. In all other contexts, Purepecha uses the -itu marker as the unique form for the diminutive category respecting the impossibility of marking gender in the language. This strategy has also been found in Central Mexicano when Mexicano speakers use Mexicano nouns and Spanish adjectives in a nominal phrase; they generally use the masculine form for the adjective, "regardless of any natural gender of the noun" (Hill \& Hill 1986: 266): 
Central Mexicano (Hill \& Hill 1986: 266)

In no-nān-tzinn, poderos-o

ART POS1-mother-DIM powerful-MASC

'As for my mother, she is powerful.'

Field (2002: 134) explains this choice as "a result of the relative frequency of such forms." For Purepecha, except for first names, the form for the diminutive category is the -itu suffix, irrespective of gender. In Purepecha, -itu does not correspond to a masculine gender because there is no opposition between two given forms.

\subsection{2. -ita with borrowings and -ito in all contexts}

In Mexicanero de la Sierra Madre Occidental, the feminine form appears only with morphemes borrowed from Spanish feminine forms, such as yerba in (41), or forms that use -ita in Spanish, such as penita in (42). In Spanish, this adverb is apenas and the diminutive form is apenitas.

Mexicanero de la Sierra Madre Occidental (Canger 2001: 58)

(41) kampa $\phi$-ki-mati ke $\phi$-onka de in yerba-ita

where S3-OBJ3SG-know that s3-exist of the plant-DIM

'Where he knows that there is some medicine herb.'

Mexicanero de la Sierra Madre Occidental (Canger 2001: 137)

$\begin{array}{ll}u \text { - } \phi \text {-nitf-tsopini } & \text { in wisti pen-ita } \\ \text { PRET-S3-OBJ1SG-knock in the } & \text { thorn barely-DIM }\end{array}$

'The thorn barely pricked me.'

In the two examples above, it seems that Mexicanero speakers have borrowed the entire form without analyzing -ita as a suffix, thus they are lexical borrowings.

The masculine form -ito is used in all contexts, with borrowings such as the noun pero 'dog' in (43) and with native items such as the adjective tepitfi 'little' or the noun mekat.

Mexicanero de la Sierra Madre Occidental (Canger 2001: 47)

$\begin{array}{llll}\text { ni-tilana-ti-ka } & \text { no-pero-ito } & \text { nel } & \text { se } \\ \text { S1SG-pull out-LIG-exist } & \text { POS1SG-dog-DIM } & \text { I } & \text { one } \\ \text { tepitfi' }{ }^{9} \text {-ito } \quad k a \quad \text { se meka-t-ito } & & \\ \text { little-DIM with one } & \text { string-SG-DIM } & & \\ \text { 'But, I am pulling out my tiny doggy with a little string.' } & \end{array}$

Mexicanero speakers seem to make a gender agreement in nominal phrases. Nevertheless, the different examples show that the unique possible marker is -ito. In examples (44) and (45), the nouns take the -ito form. Note that Mexicanero has no

9 This morpheme $\boldsymbol{t} \boldsymbol{f} \boldsymbol{i}$ is a trace of the diminutive marker $\boldsymbol{t s i}$ but it has lost its diminutive meaning (Canger 2009 p.c., see above 4.3.3.). 
gender, and in Spanish these words have feminine gender: in (44), nakas '(la) oreja' and in (45) yakatsul '(la) nariz'. The adjectives tepit $f i$ in (44), and neftik in (45) are also marked by the -ito marker. This is not a gender agreement but a repetition of -ito, since this marker cannot be opposed to any other form.

Mexicanero de la Sierra Madre Occidental (Canger 2001: 42)

$i \quad$ nin-nakas-ito medyo tepitfi-tfih-ito- $h$

and 3PL-ear-DIM half little-PL-DIM-PL

'And their tiny ears almost little.'

(45) nin-yakatsul-ito neh-neftik-ito-h

3PL-nose-DIM PL-grey-DIM-PL

'Their tiny grey noses'

These examples provide new evidence for considering that gender distinction is ignored (apart from its use with first names) in replica languages, and that -ito is the form chosen as the unique marker for the diminutive category. More evidence is given by example (46): the Spanish ahorita 'right now' (see above ex (9)) is probably one of the most frequent words in everyday conversations in Mexico (much more than ahora 'now'). The morpheme ahorita is made up of two elements: ahora 'now' and the diminutive element with the feminine form -ita. In Mexicanero, the replica of ahorita adopts the -ito diminutive form.

Mexicanero de la Sierra Madre Occidental (Canger 2001: 56)

si afka-ito'sí ahorita'

\subsection{Borrowing of -ito and -ita}

The last type is represented by Yucatec Maya, where the two Spanish diminutive markers are accepted, and along with them the gender distinction. They are used with both borrowed and native morphemes, as in (47) and (48). In these examples, the diminutive on the adjective agrees in gender with the modified noun, which is always biologically based.

(47a) polok-ito le boox-ito-o'

fat-DIM DEM dark/Maya man-DIM-DEM

'The Maya man is fat/chubby.'

(47b) bek'ech-ita $u \quad$ y-íts'in

thin-DIM A3SG POS-younger sister

'His younger sister is slender.' 


$\begin{array}{llll}\text { (48a) } & \text { sak-ito } & \text { in } & \text { suku'un } \\ \text { white-DIM } & \text { POS1SG } & \text { elder brother } \\ \text { 'My elder brother is whiter.' } & \\ \text { (48b) } & \text { xlo'obayan-ita } & \text { in } & \text { kiik } \\ \text { young-DIM } & \text { POS1SG } & \text { elder sister }\end{array}$

'My elder sister is youthful'

Briceño Chel (a native speaker and linguist of Yucatec Maya who studies his language) indicates that the use of the feminine form is recent and not as frequent as the masculine form. The forms are always used with biologically based noun. Briceño Chel specifies that examples such as (48b) would perhaps not be accepted by all Mayan speakers. But he recognizes that the distinction between feminine and masculine gender is increasing in this context.

\subsection{Double diminutives}

It is possible to observe the use of a Spanish diminutive marker with a native diminutive device. In (49), in Central Mexicano, double diminutives are used for subjective meaning, e.g. as honorifics. The examples in (49) can be contrasted with the examples in (33).

Central Mexicano (Hill \& Hill 1986: 195)

(49a) comadritáhtzīn 'dear co-mother'

(49b) compadritóhtzīn 'dear co-father'

In Purepecha in (50) and in Yucatec Maya in (51) (the examples contrast with examples (19) and (20)), double diminutives are used for descriptive meaning, for intensification, to reinforce the idea that something or someone is small:

Purepecha (Cuanajo)

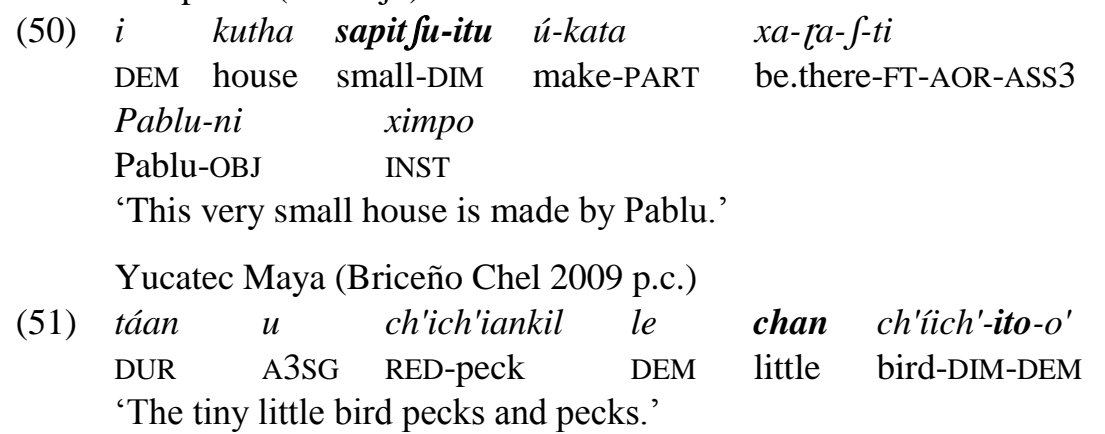




\section{Final thoughts}

\subsection{Borrowing patterns of Spanish diminutive markers}

The relevant factor that motivates the borrowing of Spanish diminutive markers is a structural property of the replica languages, that is, the use of a specific suffix. There are two different situations.

On the one hand, the motivation is to use a specific marker, a suffix. Such is the case in Purepecha and Yucatec Maya, where the use of Spanish markers has added a morphological mechanism that coexists with the native device. The languages have acquired a specific suffix that corresponds to their typological characteristics, showing functional and structural congruence (Winford 2003: 92-93, Matras 2007: 34).

On the other hand, the motivation is convergence between suffixes. This is illustrated by the different varieties of Nahuatl where two specific derivative suffixes exist, -tsin and -tōn (-to). The former is generally used for expressing subjective meanings, as an honorific for example (except in Balsas Nahuatl, see ex. (25)). According to Canger (2009 p.c.), the diminutive suffix -tōn (-to) only exists in few central varieties, and it seems to be unproductive. Tuggy (1979: 34) says about -tun: "This reflex of the historical DIM -toon survives on a large class of nouns, but its DIM force is lost in most cases and it tends to function as an ABS [absolutive]." In my sample, Acaxochitlán Nahuatl (Lastra de Suárez 1980) is the only variety where the Nahuatl diminutive suffix -to appears (see ex. (27)); in the others, the Spanish diminutive markers are used, except in Balsas Nahuatl where neither the Spanish diminutive marker nor the Nahuatl diminutive suffix -ton are attested (Flores Farfán 2009 p.c.).

The present situation seems to be the result of convergence between the Nahuatl suffixes and the Spanish markers on three levels: on the morphological level (where they are suffixes), on the semantic level (where they express descriptive and subjective meanings), and on the phonological level for the -to form (-tol-ito are quasi homophonous). ${ }^{10}$

The relation between the two diminutive markers has been stressed by various authors. Dávila Garibi (1959) proposes that the use of the diminutive marker in Mexican Spanish is influenced by Nahuatl. His principal argument is that -ito/-ita are very frequent and often seem to have a somewhat reverential sense. Nevertheless, uses such as abuelita 'dear grandmother' for example have a Spanish history and can be interpreted as a diminutive of endearment. Hill \& Hill (1986: 196) indicate that "some local bilingual usages do suggest that Mexicano is the source of use of the Spanish

10 Similarly, Flores Farfán (2008: 44) poses possible convergence between two words meaning 'little' that use a diminutive form: the Spanish chiquito (chico-ito) 'little-DIM' and the Nahuatl tzitzīqui-tōn 'tiny-DIM'. 
diminutive". In (52a), this is a very polite usage, it seems likely that sus personitas is a replica from the Nahuatl expression in (52b):

Central Mexicano (Hill \& Hill 1986: 196)

(52a) sus personitas de ustedes

(52b) namomāhuizotzitzīin

'your respected persons'

'your reverences'

Exploring factors that motivate the borrowing of Spanish diminutive markers, there are clearly additional factors involved, such as intensity of exposure to the source language, frequency of use of the diminutive category, and semantic, formal and functional transparencies of the markers.

The borrowing of Spanish diminutive markers reveals the high intensity of exposure of these languages to Spanish, in terms of duration -almost five centuries- and of the cultural and socioeconomic dominance of the group of monolingual Spanish speakers. The degree of interference of these languages with Spanish is at Stage 3 ('more intense contact') or 4 ('intense contact') in terms of Thomason's borrowing scale. At these stages, "derivational affixes may be borrowed. [...] In morphology, borrowed inflectional affixes and categories may be added to native words, especially if they fit well typologically with previously existing patterns." (Thomason 2001: 69-70). However, intensity is not sufficient because other languages of Mesoamerica that have the same intensity of exposure to Spanish have not borrowed these markers, such as Otomi (Hekking \& Bakker 2007). For example, Santiago Mexquititlán Otomi has two specific diminutive proclitics, $t s i$ for subjective meaning, e.g. affection, tsi mbane 'dear co-father' and t'olo for descriptive meaning, t'olo mexa 'small table' (Hekking, 2009, p.c.).

Another factor is the very high use frequency of the diminutive category in Spanish as well as in the replica languages, especially in Nahuatl.

This study also shows the role of transparency as a general cognitive principle that regulates the transfer of morphemes across linguistic systems (Field 2002, Winford 2003 and Matras 2007): the Spanish diminutive markers show semantic, formal and functional transparencies. On the semantic level, Spanish diminutive markers are used in the replica languages for the same meanings as the native devices: descriptive meaning $(43,50,51)$ and some positive subjective meaning, to express affection or respect $(31,35,36,49)$ and to provide a shade of meaning $(38,42)$.

Other languages that have not borrowed diminutive Spanish markers have a specific device for each meaning. For example, in Popoluca - a Mixe-Zoquean language - for descriptive meaning, a lexical mechanism is used, the morpheme xutyu' 'little', xutyu' mooya 'little flower', and for subjective meanings, reduplication or specific morphemes are used, xuxutymooya 'lovely flower (for a woman)' (Gutiérrez Morales 2009, personal communication). 


\subsection{Acceptance of grammatical gender}

According to Field (2002: 195-196), typological aspects of the languages involved in a contact situation put certain constraints on what may be borrowed, for example whether a given category exists in the replica language. The possibility for gender distinctions to be accepted is a clear example of the existence of a constraint: the absence of grammatical gender distinction in the majority of replica languages analyzed does not prevent borrowing of the Spanish diminutive, but does not allow for acceptance of grammatical gender. The -ito marker is treated by these languages as the unique form for the diminutive category. On the contrary, Yucatec Maya that already has two gender markers accepts the two markers -ita and -ito and the gender distinction, but no agreement. So far, this distinction is restricted to biologically based nouns while the gender prefixes $a j-/ j$ - and $i x-/ x$ - are accepted in different contexts (see above 4.4).

The data presented here are far from sufficient. Today, the motivations for borrowing Spanish diminutive markers in certain Mesoamerican languages and the typological constraints on accepting gender distinction are to be regarded simply as hypotheses to be tested.

\section{Abbreviations}

$\begin{array}{llll}\text { A } & \text { ergative } & \text { MASC } & \text { masculine } \\ \text { AOR } & \text { aorist } & \text { MID } & \text { middle } \\ \text { APP } & \text { applicative } & \text { OBJ } & \text { object } \\ \text { ART } & \text { article } & \text { PART } & \text { participle } \\ \text { ASS } & \text { assertive } & \text { PAST } & \text { past } \\ \text { DEM } & \text { demonstrative } & \text { PFV } & \text { perfective } \\ \text { DIM } & \text { diminutive } & \text { PL } & \text { plural } \\ \text { DUR } & \text { durative } & \text { POS } & \text { possessive } \\ \text { FEM } & \text { feminine } & \text { PRET } & \text { preterit } \\ \text { FOC } & \text { focus } & \text { PRED } & \text { predicativizer } \\ \text { FT } & \text { formative } & \text { RED } & \text { reduplication } \\ \text { FUT } & \text { future } & \text { REF } & \text { reflexive } \\ \text { HAB } & \text { habitual } & \text { S } & \text { subject } \\ \text { IMP } & \text { imperative } & \text { SG } & \text { singular } \\ \text { INF } & \text { infinitive } & \text { SUB } & \text { subordinating conjunction } \\ \text { INST } & \text { instrumental } & \text { SUBJ } & \text { subjunctive } \\ \text { LIG } & \text { linker } & \text { Z.CENTR } & \text { central zone }\end{array}$




\section{References}

Aronoff, Mark (1994): Morphology by itself. Cambridge: The MIT Press.

Campbell, Lyle, Kaufman, Terrence \& Smith Stark, Thomas (1986): Meso-america as a linguistic area, in: Language 62(3), 530-570.

Canger, Una (2001): Mexicanero de la Sierra Madre Occidental. México: El Colegio de México.

Chamoreau, Claudine (2007): Grammatical borrowing in Purepecha, in: Matras, Yaron \& Sakel, Jeanette (eds.), Grammatical borrowing in cross-linguistic perspective. Berlin: Mouton de Gruyter, 465-480.

Chamoreau, Claudine (2009): Hablemos purepecha, Wantee juchari anapu. México: uiim/iihumsnh/ird/Ambassade France au Mexique ccc-ifal/Grupo Kw'anískuyarhani.

Corbett, Greville (1991): Gender. Cambridge: Cambridge University Press.

Dávila Garibi, José Ignacio (1959): Posible influencia del náhuatl en el uso y abuso del diminutivo en el español de México, in: Estudios de Cultura Náhuatl 1, 91-94.

Field, Fredric (2002): Linguistic borrowing in bilingual contexts. Amsterdam: John Benjamins.

Fischer, Steven Roger (2007): Grammatical borrowing in Rapanui, in: Matras, Yaron \& Sakel, Jeanette (eds.), Grammatical borrowing in cross-linguistic perspective. Berlin: Mouton de Gruyter, 387-401.

Flores Farfán, José Antonio (1999): Cuatreros somos y toindioma hablamos. Contactos y conflictos entre el náhuatl y el español en el sur de México. México: CIESAS.

Flores Farfán, José Antonio (2008): The Hispanisation of modern Nahuatl varieties, in: Stolz, Thomas, Bakker, Dik \& Salas Palomo, Rosa (eds), Hispanisation. The impact of Spanish on the lexicon and grammar of the indigenous languages of Austronesia and the Americas. Berlin: Mouton de Gruyter, 27-48.

González Casanova, Pablo (1933): Los Hispanismos en el Idioma Azteca, México, in: Anales del

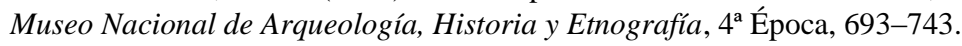

Hekking, Ewald \& Bakker, Dik (2007): The case of Otomi: a contribution to grammatical borrowing in cross-linguistic perspective, in: Matras, Yaron \& Sakel, Jeanette (eds.), Grammatical borrowing in cross-linguistic perspective. Berlin: Mouton de Gruyter, 435-464.

Hill, Jane \& Hill, Kenneth (1986): Speaking Mexicano. Dynamics of syncretic language in Central Mexico. Tucson: The University of Arizona Press.

Jurafsky, Daniel (1996): Universal tendencies in the semantics of the diminutive, in: Language 72(3), 533-578.

Kung, Susan Smythe (2007): A descriptive grammar of Huehuetla Tepehua. PhD Dissertation. Austin: The University of Texas.

Lastra de Suárez, Yolanda (1980): Náhuatl de Acaxochitlán (Hidalgo). México: Centro de Investigación para el Desarrollo Social.

Launey, Michel (1981): Introduction à la langue et à la litterature aztèques, tome 1: grammaire. Paris: L'Harmattan.

Lois, Ximena (1998): Gender markers as "rigid determiners" of the Itzaj Maya World, in: International Journal of American Linguistics 64(3), 224-282.

Lois, Ximena \& Vapnarsky, Valentina (2006): Root indeterminacy and polyvalence in Yukatekan Mayan languages, in: Lois, Ximena \& Vapnarsky, Valentina (eds.), Lexical categories and root classes in Amerindian languages: Bern: Peter Lang, 69-115.

Matras, Yaron (2007): The borrowability of structural categories, in: Matras, Yaron \& Sakel, Jeanette (eds.), Grammatical borrowing in cross-linguistic perspective. Berlin: Mouton de Gruyter, 31-73.

Quintal Martín, Fidelio (1999): Curso de gramática maya. Mérida: Ediciones de la Universidad Autónoma de Yucatán. 
Reynoso Noverón, Jeanett (2001): Los diminutivos en el español. Un estudio de dialectología comparada. México: Universidad Nacional Autónoma de México.

Reynoso Noverón, Jeanett (2005): Procesos de gramaticalización por subjetivización: el uso del diminutivo en español, in: David Eddigton (ed.), Selected proceedings of the 7th Hispanic linguistics symposium. Somerville: Cascadilla Proceedings Project, 79-86.

Schachter, Paul \& Otanes, Fe T. (1972): Tagalog Reference Grammar. Berkeley: University of California Press.

Smith Stark, Thomas (1994): Mesoamerican calques, in: Mackay, Carolyn \& Vázquez, Verónica (eds), Investigaciones lingüísticas en Mesoamérica. México: IIF-UNAM, 15-50.

Stolz, Christel (1998): Hispanicisation in modern Yucatec Maya: grammatical borrowing, In: Koechert, Andreas \& Stolz, Thomas (eds), Convergencia e individualidad. Las lenguas mayas entre hispanización e indigenismo. Hannover: Verlag für Ethnologie, 165-194.

Stolz Christel (2008): Loan word gender: A case of romancisation in Standard German and related enclave varieties, in: Stolz, Thomas, Salas Palomo, Rosa \& Bakker, Dik (eds.), Aspects of language contact. New theoretical, methodological and empirical findings with special focus on Romancisation processes. Berlin: Mouton de Gruyter, 399-440

Stolz, Christel (2009): A different kind of gender problem: Maltese loanword gender from a typological perspective, in Comrie, Bernard, Fabri, Ray, Hume, Elizabeth, Mifsud, Manwel, Stolz, Thomas \& Vanhove, Martine. Introducing Maltese Linguistics. Amsterdam: John Benjamins. 321354.

Stolz, Thomas (2002): General linguistic aspects of Spanish-indigenious language contacts with special focus on Austronesia, in Bulletin of Hispanic Studies 79, 133-158.

Stolz, Thomas (2008): Romancisation worldwide, in: Stolz, Thomas, Salas Palomo, Rosa \& Bakker, Dik (eds.), Aspects of language contact. New theoretical, methodological and empirical findings with special focus on Romancisation processes. Berlin: Mouton de Gruyter, 1-42.

Stolz, Thomas (this volume): Survival in a niche. On gender-copy in Chamorro (and sundry languages).

Stolz, Thomas \& Stolz, Christel (2001): Mesoamerica as a linguistic area, in: Haspelmath, Martin; König, Ekkehard; Oesterreicher Wulf \& Raible, Wolfgang (eds.), Language typology and language universals. An international handbook, Vol. 2. Berlin: Walter de Gruyter, 1139-1553.

Suárez, Jorge (1977): La influencia del español en la estructura gramatical del náhuatl, in: Anuarios de letras $15,115-164$.

Swadesh, Morris (1967): Cuatro siglos de transculturación lingüística en el porhé, in: Anales de Antropología, 161-185.

Thomason, Sarah (2001): Language contact. An introduction. Washington: Georgetown University Press.

Thomason, Sarah \& Kaufman, Terrence (1988): Language contact, creolization and genetic linguistics. Berkeley: University of California Press.

Tuggy, David (1979): Tetelcingo Nahuatl, in: Langacker, Ronald W. (ed.), Studies in Uto-Aztecan grammar. Vol. 2 Modern Aztec grammatical sketches. Arlington: SIL, 1-140.

Winford, Don (2003): An introduction to contact linguistics. Oxford: Blackwell. 


\section{Mesoamerica}
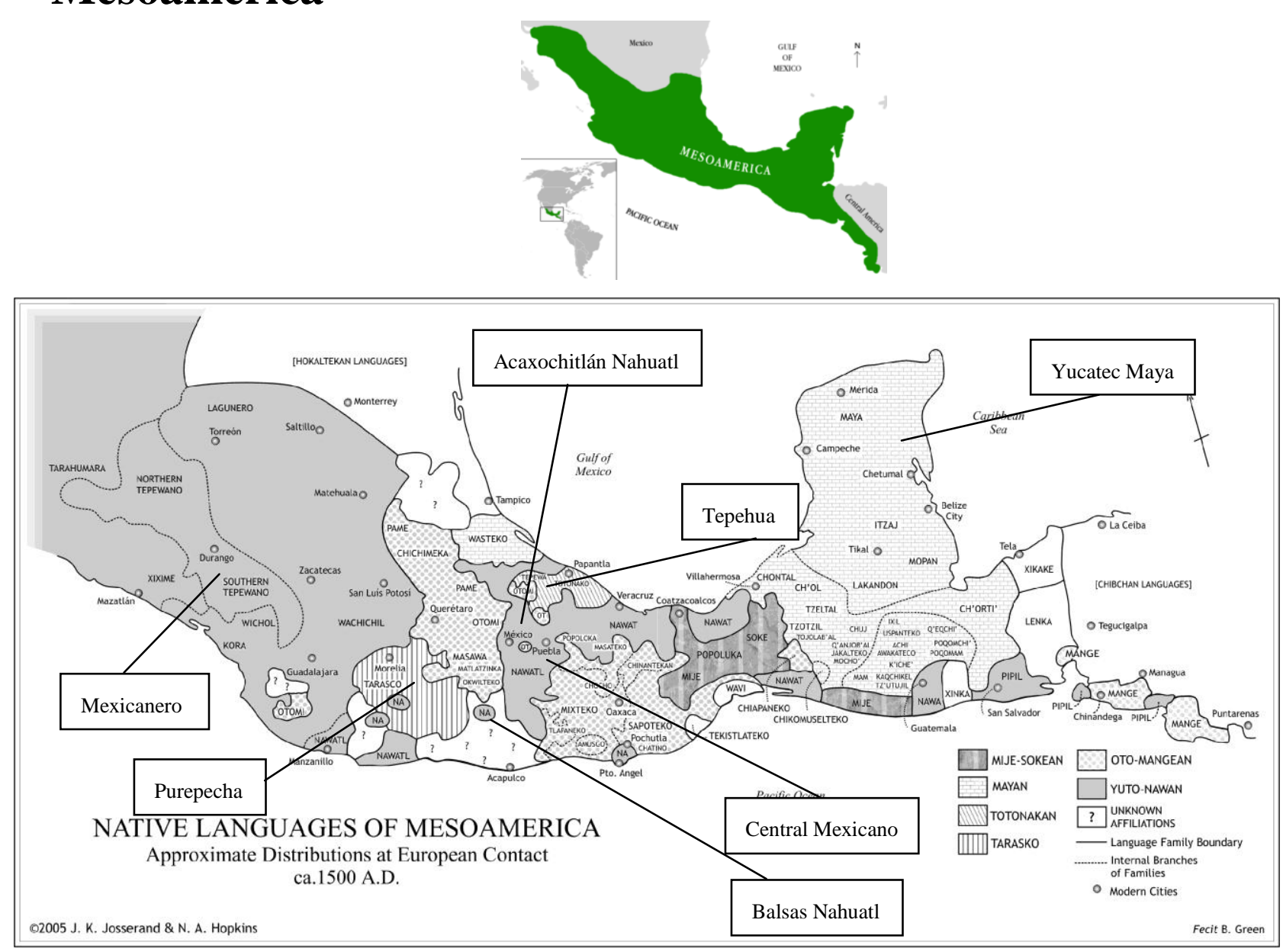